\title{
First Report on Three Cases of Monkey pox in Nord Ubangi Province (Democratic Republic of the Congo)
}

\author{
Koto-te-Nyiwa Ngbolua ${ }^{1,2,3}$, Guy Kumbali Ngambika ${ }^{2}$, Blaise Mbembo-wa-Mbembo', Kohowe \\ Pagerezo Séraphin ${ }^{4}$, Kogana Kapalata Fabrice ${ }^{2}$, Gédéon Ngiala Bongo ${ }^{1}$, Masengo Ashande \\ Colette $^{3}$, Djolu Djoza Ruphin ${ }^{2,3}$ \\ ${ }^{1}$ Department of Biology, Faculty of Science, University of Kinshasa, Kinshasa, Democratic Republic of \\ the Congo \\ ${ }^{2}$ Department of Basic Sciences, Faculty of Medicine, University of Gbado-Lite, Gbado-Lite, Democratic \\ Republic of the Congo \\ ${ }^{3}$ Department of Environment Sciences, University of Gbado-Lite, Gbado-Lite, Democratic Republic of \\ the Congo \\ ${ }^{4}$ Ubangi Medical Techniques High School, Gbado-Lite, Democratic Republic of the Congo \\ Email: jpngbolua@unikin.ac.cd
}

\begin{abstract}
:
Monkey pox is a rare viral zoonotic disease of which clinical manifestations are similar to smallpox, it is transmitted to humans by direct contact with the body of an infected animal, but the transmission can also be human-to-human. The Democratic Republic of Congo is the most endemic country in the world where almost all provinces are affected by this scourge. However, in the administrative configuration currently, monkey pox has not been detected in Nord Ubangi province yet. This cross-sectional study focuses on three cases of patients diagnosed with monkey pox virus at Businga General Hospital in Nord Ubangi province. The findings show that all the three patients were male with a primary education level and their average age was $9 \square 3.46$ years. They had some epidemiological characteristics specific to monkey pox, including high fevers, rashes, pruritus and abdominal pain. After two weeks of symptomatic treatment, each patient was able to get out without further complications. For the best of our knowledge, this is the first report on the cases of Monkey pox in Nord Ubangi Province.
\end{abstract}

Keywords:

Monkey pox virus; zoonosis; public health; Nord Ubangi; Democratic Republic of Congo.

\section{Introduction}

Monkey pox, also known as the smallpox of singe, or simian orthopoxvirus, is a rare zoonotic viral infection caused by the monkey pox virus, a genus of orthopoxvirus of the Poxviridae family (Nolen et al., 2015; Li et al., 2017; Kara et al., 2018). Historically, monkey pox was detected and isolated for the first time in Copenhagen (Denmark) in 1958, on Macaca cynomolgus (11.5 in the territory of Basankusu (Province of Equateur) in 1970 in a male child of nine months during the eradication of smallpox (Ladnyi et al., 1972; Breman et al., 1980). Later, it has been reported in other Western and Central African countries namely Nigeria, Cameroon, Gabon, Central African Republic, Ivory Coast, Sierra Leone and Liberia. This endemic circulates in the rainforests of Central and West Africa (Mwamba et al., 1997; Boumandouki et al., 2005).

The West African and Congo Basin Clades are the two clades of monkey pox virus known to cause endemic disease in the DRC and sporadic outbreaks in many parts of Central and West Africa as well as in the United States of America (Vaughan et al., 2018). The Congo Basin clade of virus is responsible for more severe outbreaks that are reported in most parts of Central Africa while the West Africa Clade accounts for milder outbreaks from other parts of the world (Ogoina et al., 2017). 


\section{Review of Literature}

The monkey pox virus is a serious public health problem because it is a human pathogen of which clinical presentation is like that of smallpox (Rogers et al., 2008; Quiner et al., 2017). It can be transmitted from the infected animal to humans (primary zoonotic transmission), from humans to humans via bodily fluids like blood, salivary/respiratory droplets, a lesion exudate and the crust of an infected human (Fine et al., 1988; Quiner et al., 2015). Several studies have been initiated with the aim of highlighting the hosts and reservoirs of this virus in wild mammals, particularly in monkeys, bats, squirrels and rodents; meanwhile the squirrel appears to be the most indexed animal in most published results. However, the main reservoir of human infection remains unknown until then (Mutombo et al. 1983; Khodakevich et al., 1988; Baxby, 1997; Di Giulio \& Eckburg, 2004; Nohen et al. 2015). Human monkey pox is smallpox like illnesses characterized by a prodromal of fever and malaise accompanied by progressive appearance of vesiculopustular skin lesions. The morbidity and mortality of human monkey pox is however much milder than that of smallpox (Ogoina et al., 2017).

The DRC ranks first among the most affected countries most by Monkey pox (Mwamba et al., 1997; Reynolds and Damon, 2012; Quiner et al., 2017). In DRC, mainly in the Districts of Sankuru (Eastern Kasai Province) and Tshuapa (Equateur province) are areas where the majority of reported human cases of monkey pox in the world (Rimoin et al., 2007; McCollum et al., 2015; Public Health Ministry, 2017), with the largest epidemic record in 1996 in Katako Kombe with 832 cases $(78 \%)$ of which were secondary cases. However, no studies have yet reported the presence of this disease in Nord Ubangi province. The aim of this monograph was to report three cases of Monkey pox detected at the General Hospital of Businga in Nord Ubangi province, DRC.

\section{Discussion}

This cross-sectional study focuses on the cases of three children with Vesiculo-pustuleous rashes, which are widespread on the whole body and followed by fever. They have been transferred to Businga General Hospital in the Province of Nord Ubangi between April and May 2019. The table below gives the clinical aspects of the three cases of monkey pox diagnosed in Businga General Hospital.

Table 1. Clinical aspects of the three cases of monkey pox

\begin{tabular}{ccccccccc}
\hline No & Sex & $\begin{array}{c}\text { Age } \\
\text { (year) }\end{array}$ & $\begin{array}{c}\text { Average } \\
\text { age (year) }\end{array}$ & Education level & Fever & $\begin{array}{c}\text { Skin } \\
\text { eruption }\end{array}$ & $\begin{array}{c}\text { Prurit } \\
\text { us }\end{array}$ & $\begin{array}{c}\text { Abdominal } \\
\text { pain }\end{array}$ \\
\hline 1 & M & 13 & & Primary school & + & + & + & - \\
2 & M & 7 & $9 \pm 3.46$ & Primary school & + & - & - & - \\
3 & M & 7 & & Primary school & + & + & + & + \\
\hline
\end{tabular}

The data presented on the table above show that all infected patients were male, a rate of $100 \%$ with high fever. Two of them presented skin eruption and pruritus while the last presented also abdominal pain. The second patient did not show any skin eruption nor pruritus and abdominal pain. These results are similar, but far higher, to those reported by Quiner et al. (2017) and Osadebe et al. (2017), first found that $64 \%$ of patients infected with the monkeypox virus were male while the latter found a rate of $53 \%$. The average age found in this study is 
$9 \pm 3.46$ years, this finding corroborates with that found in Congo Brazzaville by Boumandouki et al. (2005) who reported an average age of $9.05 \pm 5.86$ years out of 8 positive cases of monkey pox. Numerous studies have found rashes and high fevers in patients infected with monkey pox virus, especially in children (Tochokoteu et al., 1997; Boumandouki et al., 2005; Kathan et al., 2015; Osadebe et al., 2017).

The figures below show the three cases of infants infected by monkey pox virus.

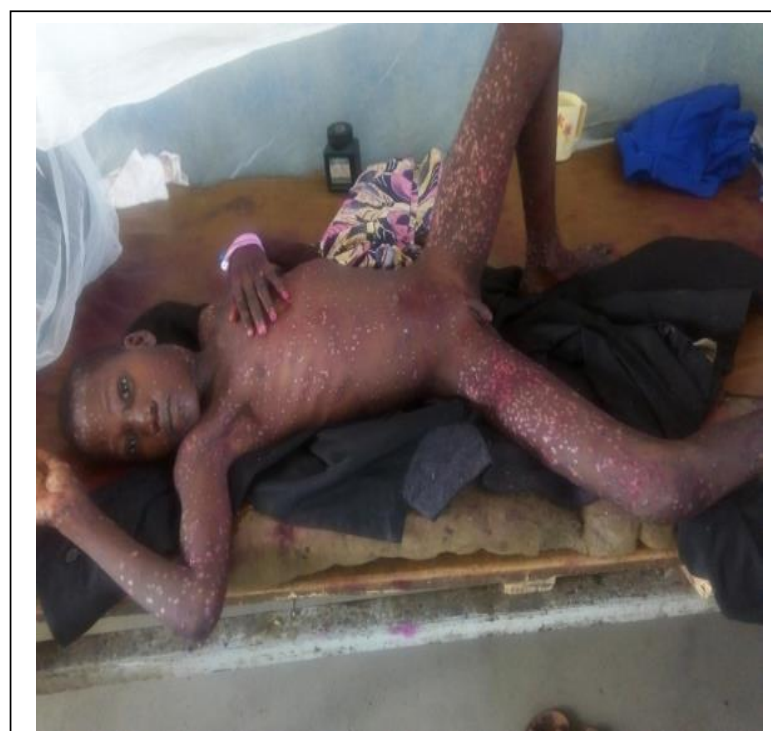

(a)

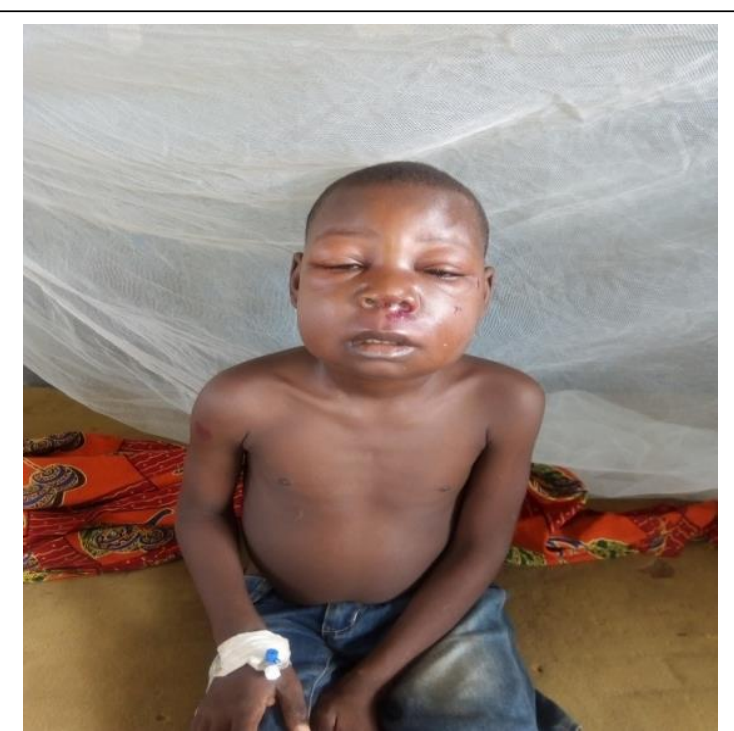

(b)

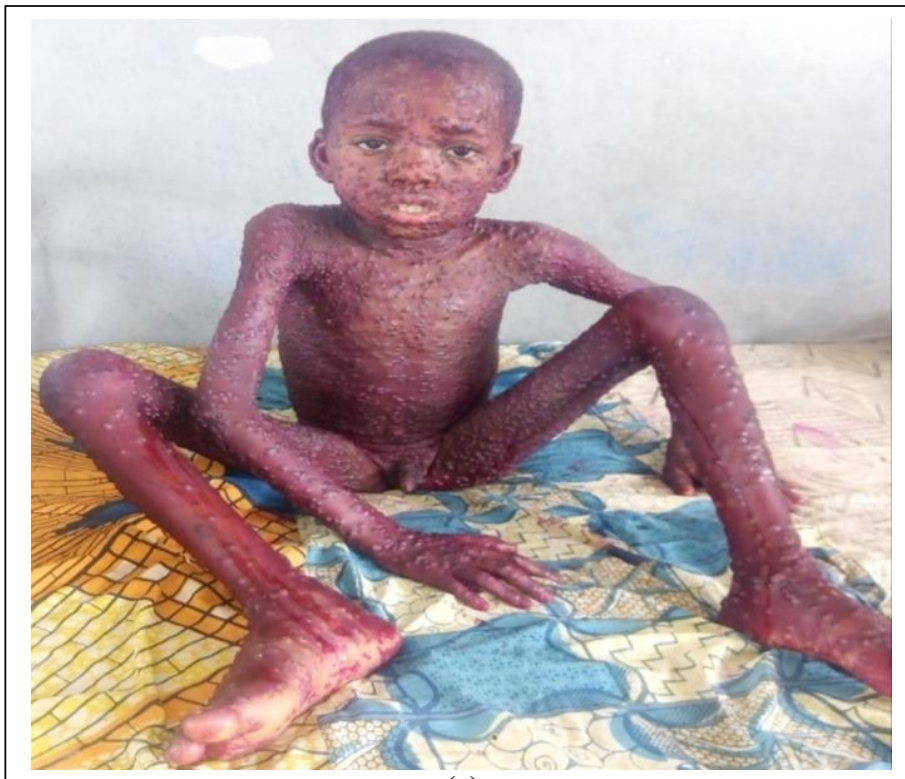

(c)

Figure 1. Patients affected by monkey pox

The figure 1 above show the three cases of children infected with the monkey pox virus. The first case (figure 1a) is that of a 13-year-old child who is a trapper of rats and squirrels prized by the whole family. 
The second case (figure $1 \mathrm{~b}$ ) is that of his younger brother, 7 years old, probably contaminated by his big brother, but diagnosed early. One study pointed out that staying overnight in the same house or on the same bed, sharing food in one container would be the main pathways to the risk of contracting monkey pox in a household; thus, the first two cases belong to the same family (Nolen et al., 2017).

The elder was the first to get sick by presenting vesiculopustular eruptions on the head, palms of the hands, foot plants and then generalized accompanied by high fevers. Being in contact with the carcasses of infected animals, listed above, is believed to be the source of the transmission of the virus from animals to humans, and from humans to humans as the case between these two brothers (Khodakevich et al. 1988; Di Giulio \& Eckburg, 2004; Nakazawa et al., 2013).

The third case concerns a 7-year-old child who was transferred to the Businga Reference General Hospital for vesicular-pustular rashes, generalized to the body, as well as pruritus with abdominal pain. We report here that the three cases of patients infected with monkey pox, have an age range between 7 and 13 years. These results are identical to those published by the Ministry of Health in 2012 (Public Health Ministry, 2017), which reported that the age group of 5 to 14 years was the most affected by monkey pox.

\section{Conclusion}

Monkey pox remains a public health problem in DRC. In fact, not yet mentioned in a report on the provinces affected by this endemic, Nord Ubangi can be added to this list. This study should challenge the authorities of the country on the presence of this disease in this part of the country, and possibly call on them to play their full role in order to sensitize the population on the preservation against this disease.

\section{Acknowledgements}

The authors are indebted to Professor Ngbolua Koto-te-Nyiwa, the Chancellor of the University of Gbado-Lite and Principal investigator of "Ubangi BioXplore" project for the promotion of scientific research on the biodiversity of the Ubangi eco-region.

\section{References}

Baxby, D. (1997). Poxvirus Hosts and Reservoirs: Brief Review. Archives of Virology, 55, 169179.

Boumandouki, P., Bileckot, R., Ibara, J.R., Satounkazi, C., Wassa Wassa, D., Libama, F., Moudzeo, H., Bolanda, J.D., Ngokaba, C. (2005). Orthopoxvirose simienne (ou variole du singe) : étude de 8 cas observés à l'hôpital d'Impfondo de la République du Congo. Bull. Soc. Pathol. Exot., 100(1),17-21.

Breman, J.G., Kalisa, R., Steniowski, M.V., Zanotto, E., Gromyko, A.I., Arita, I. (1980). Human monkeypox: 1970-79. Bulletin of the World Health Organization, 58 (2), 165-182.

Di Giulio, B.D., $\quad$ Eckburg, B.P. (2004). Human monkeypox: an emerging zoonosis. Lancet Infect. Dis., 4(1), 15-25.

Fine, P.E., Jezek, Z., Grab, B., Dixon, H. (1988). The transmission potential of monkeypox virus in human populations. Int J Epidemiol., 17(3), 643-50.

Kalthan, E., Dondo-Fongbia, J.P., Yambele, S., Dieu-Creer, L.R., Zepio, R., Pamatika, C.M. (2015). Epidémie de 12 cas de maladie à virus monkeypox dans le district de Bangassou en 
République Centrafricaine en décembre 2015. Bull. Soc. Pathol. Exot. doi, 10.1007/s13149-016-0516-z.

Kara, N.D., McCollum, M.A., Nakazawa, Y., Petersen, W.B., Reynolds, G.M., Briand, S., Djingarey, H.M., Olson, V., Damon, K.I., Khalakdina, A. (2018). Emergence of Monkeypox-West and Central Africa, 1970-2017. MMWR, 67(10), 306-310.

Khodakevich, L., Ježek, Z., Messinger, D. (1988). Monkeypox virus: ecology and public health significance. Bull World Health Organ., 66(6), 747-752.

Ladnyj, I.D., Ziegler, P., Kima, E. (1972). A human infection caused by monkeypox virus in Basankusu Territory, Democratic Republic of the Congo. Bull. World Health Organ., 46(5), 593-597.

Li, D., Wilkins, K., McCollum, M.A., Osadebe, L., Kabamba, J., Nguete, B., Likafi, T., Balilo, P.M., Lushima, S.R., Malekani, J., Damon, K.I., Vickery, C.L.M., Pukuta, E., Nkawa, F., Karhemere, S., Muyembe, T.J.J., Okitolonda, W.E., Li, Y., Reynolds, G.M. (2017). Evaluation of the GeneXpert for Human Monkeypox Diagnosis. Am. J. Trop. Med. Hyg., 96(2), 405-410.

Magnus, P.V., Andersen, E.K, Petersen, K.B., Birch-Andersen, A. (1958). A pox-like disease in cynomolgus monkeys. Acta Pathol. Microbiol. Scand., 46, 156-176.

McCollum, M.A., Nakazawa, Y., Ndongala, M.G., Pukuta, E., Karhemere, S., Lushima, S.R., Ilunga, K.B., Kabamba, J., Wilkins, K., Gao, J., Li Y., Emerson, G., Damon, K.I., Carroll, S.D., Reynolds, G.M., Malekani, J., Muyembe, T.J.J. (2015). Case Report: Human Monkeypox in the Kivus, a Conflict Region of the Democratic Republic of the Congo. Am. J. Trop. Med. Hyg., 93(4), 718-721.

Ministère de la Santé Publique (RDC): Direction de lutte contre la maladie (2017). Guide de prise en charge des épidémies dans une Zone de santé : Monkeypox. 2è edition, p48.

Mutombo, J., Arita, I., Jezek Z. (1983). Human monkeypox transmitted by a chimpanzee in a tropical rain-forest area of zaire. Lancet Infect. Dis., 321(8327), 735-737.

Mwamba, P.T., Tshioko, K.F., Moudi, A., Mukinda, V., Mwema, G.N., Messinger, D., Okito, L., Barakymfyte, D., Malfait, P., Pebody, R., Szczeniowski, M., Esteves, K., Heymann, D., Hutin, Y., Williams, R.J., Khan, A.S., Esposito, J.J. (1997). Rapport d'investigation. Des cas humains d'orthopoxvirose simienne au Kasaï oriental, Zaîre (1996-1997), Euro surveillance, 2(5), 33-35.

Nakazawa, Y., Emerson, L.G., Carroll, S.D., Zhao, H., Li, Y., Reynolds, G.M., Karem, L.K., Olson, A.V., Lash, R.R., Davidson, B.W., Smith, K.S., Levine, S.R., Regnery, L.R., Sammons, A.S., Frace, A.M., Mutasim, M.E., Karsani, E.M.M., Muntasir, O.M., Babiker, A.A., Opoka, L., Chowdhary, V, Damon, K.I. (2013). Phylogenetic and Ecologic Perspectives of a Monkeypox Outbreak, Southern Sudan, 2005. Emerging Infectious Diseases, 19(2), 237-246.

Nolen, L.D., Osadebe, L., Katomba, J., Likofata, J., Mukadi, D., Monroe, B., Doty, J., Kalemba, L., Malekani, J., Kabamba, J., Bomponda, L.P., Lokota, I.J., Balilo, P.M., Likafi, T., Lushima, S.R., Muyembe, T.J.J., Okitolonda, W.E., McCollum, M.A., Reynolds, G.M. (2015). Introduction of Monkeypox into a Community and Household: Risk Factors and Zoonotic Reservoirs in the Democratic Republic of the Congo. Am. J. Trop. Med. Hyg., 93(2), 410-415.

Ogoina, D., Izibewule, J.H., Ogunleye, A., Ederiane, E., Anebonam, U., Aworabhi, N., Oyeyemi, A., Etebu, E.N., Ihekweazu, C. (2017). The 2017 human monkeypox outbreak in NigeriaReport of outbreak experience and response in the Niger Delta University Teaching Hospital, Bayelsa State, Nigeria. Plos One, 14(2), e0214229. https:// doi.org/10.1371/journal.pone.0214229

Osadebe, L., Hughes, M.C., Lushima, S.R., Kabamba, J., Nguete, B., Malekani, J., Pukuta, E., Karhemere, S., Muyembe, T.J.J., Okitolonda, W.E., Reynolds, G.M., McCollum, M.A. 
(2017). Enhancing case definitions for surveillance of human monkeypox in the Democratic Republic of Congo. PLoS Negl Trop Dis; 11(9), e0005857. https://doi.org/10.1371/journal.pntd.0005857.

Quiner, C.A., Moses, C., Monroe, B.P., Nakazawa, Y., Doty, B.J., Hughes, M.C., McCollum, M.A., Ibata, S., Malekani, J., Okitolonda, E., Carroll, S.D., Reynolds, G.M. (2017) Presumptive risk factors for monkeypox in rural communities in the Democratic Republic of the Congo. PLoS One, 12(2), e0168664. doi:10.1371/journal.pone.0168664.

Reynolds, M.G., Damon, I.K. (2012). Outbreaks of human monkeypox after cessation of smallpox vaccination. Trends Microbiol., 20(2), 80-87.

Rimoin, A.W., Kisalu, N., Kebela-Ilunga, B., Mukaba, T., Wright, L.L., Formenty, P., Wolfe, N.D., Shongo, R.L., Tshioko, F., Okitolonda, E., Muyembe, J.J., Ryder, R., Meyer, H. (2007). Endemic human monkeypox, Democratic Republic of Congo, 2001-2004. Emerg. Infect. Dis., 13(6), 934-937.

Rogers, V.J., Parkinson, V.C., Choi, W.Y., Speshock, L.J., Hussain M.S. (2008). A Preliminary Assessment of Silver Nanoparticle Inhibition of Monkeypox Virus Plaque Formation. Nanoscale Res. Lett., 3, 29-133. DOI 10.1007/s11671-008-9128-2.

Tochokoteu, P., Kago, I., Tetanye, E., Ndoume, P., Pignon, D., Mbede, J. (1991). Variole ou varicelle grave ? Un cas de variole humaine a Monkeypox virus chez un enfant Camerounais. Ann. Soc. Belge Méd. Top., 71, 123-128.

Vaughan, A., Aarons, E., Astbury, J., Balasegaram, S., Beadsworth, M., Beck Beck, R.C., Chand Chand, M., O'Connor, C., Dunning, J., Ghebrehewet, S., Harper, N., Howlett-Shipley, R., Ihekweazu, C., Jacobs, M., Kaindama, L., Katwa, P., Khoo, S., Lamb, L., Mawdsley, S., Morgan, D., Palmer, R., Phin, N., Russell, K., Said, B., Simpson, A., Vivancos, R., Wade, M., Walsh, A., Wilburn, J. (2018). Two cases of monkeypox imported to the United Kingdom, September 2018. Euro Surveill., 23(38), 1800509. doi: 10.2807/15607917.ES.2018.23.38.1800509. 